\title{
BIOMECHANICAL STUDY OF TRANSCORTICAL OR TRANSTRABECULAR BONE FIXATION OF PATELLAR TENDON GRAFT WITH BIOABSORBABLE PINS IN ACL RECONSTRUCTION IN SHEEP
}

Mauro Batista Albano', Paulo César Borges², Mario Massatomo Namba ${ }^{3}$, João Luiz Vieira da Silva ${ }^{4}$, Francisco de Assis Pereira Filho ${ }^{5}$, Edmar Stieven Filho ${ }^{6}$, Jorge Eduardo Fouto Matias ${ }^{7}$

\section{ABSTRACT}

Objective: To determine the initial resistance of fixation using the Rigid Fix ${ }^{\circledR}$ system, and compare it with traditional fixation methods using metal interference screws; and to evaluate the resistance of the fixation with the rigid fix system when the rotational position of the bone block is altered in the interior of the femoral tunnel. Methods: forty ovine knee specimens (stifle joints) were submitted to anterior cruciate ligament reconstruction (ACL) using a bone-tendon-bone graft. In twenty specimens, the Rigid Fix method was used; this group was subdivided into two groups: ten knees the pins transfixed only the spongious area of the bone block, and ten for fixation passing through the layer of cortical bone. In the twenty remaining specimens, the graft was fixed with $9 \mathrm{~mm}$ metal interference screws. Results: comparison of the RIGIDFIX ${ }^{\circledR}$ method with the metal interference screw fixation method did not show any statistically significant differences in terms of maximum load and rigidity; also, there were no statistically significant differences when the rotational position of the bone block was altered inside the femoral tunnel. For these evaluations, a level of significance of $p<0.017$ was considered. Conclusion: fixation of the bone-tendonbone graft with 2 bioabsorbable pines, regardless of the rotational position inside the femoral tunnel, gave a comparable fixation in terms of initial resistance to the metal interference screw, in this experimental model.

Keywords - Anterior Cruciate Ligament; Bone-Patellar Tendon-Bone Graft; Knee; Sheep

\section{INTRODUCTION}

In reconstructing the anterior cruciate ligament, graft fixation is an extremely important factor. The fixation method has to be rigid and resistant to traction forces so that postoperative rehabilitation using current principles can be applied ${ }^{(1)}$.

Autografts are preferred because of their low complication rate. Among these, the ones most used in anterior cruciate ligament reconstruction surgery are the flexor tendons (semitendinosus and gracilis), bonetendon-bone removed from the patella, the central third of the patellar tendon and the anterior tuberosity of the tibia. Bone-tendon-bone grafts enable rigid fixation inside the tunnels. The fixation technique using interference screws is the one most used for this graft and is considered to be the gold standard for fixation ${ }^{(2-8)}$.

However, large numbers of complications from using interference screws for graft fixation in ligament

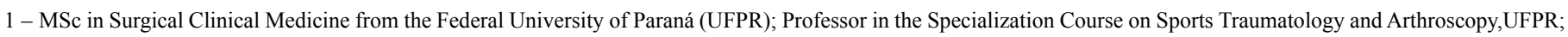
Member of the Orthopedics and Traumatology Service, Hospital do Trabalhador, UFPR, Curitiba, PR, Brazil.

2 - PhD in Mechanical Engineering; Professor in the Academic Department of Mechanics, Federal Technological University of Paraná (UTFPR), Curitiba, PR, Brazil.

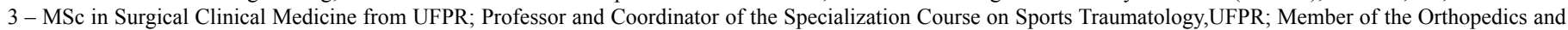
Traumatology Service, UFPR, Curitiba, PR, Brazil.

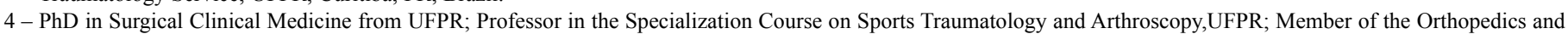
Traumatology Service,UFPR, Curitiba, PR, Brazil.

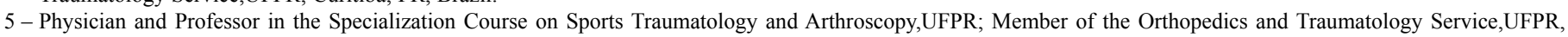
Curitiba, PR, Brazil.

6 - Physician andProfessor in the Specialization Course on Sports Traumatology and Arthroscopy,UFPR, Curitiba, PR, Brazil

7 - PhD in Surgical Clinical Medicine. Adjunct Professor in the Department of Surgery, UFPR, Curitiba, PR, Brazil.

Work performed inthe Orthopedics and Traumatology Service,Federal University of Paraná (SOT-UFPR).

Correspondence: Mauro Batista Albano, Rua Padre Dehon 1119 ap 410, V. Hauer, Curitiba, PR. Tel. (41) 3287- 4221 e-mail: albano_mauro@yahoo.com.br

Received for publication: 11/24/2010, accepted for publication: 10/25/2011

The authors declare that there was no conflict of interest in conducting this work 
reconstructions have been described. The commonest of these are lesions to the graft at the bone-tendon transition at the time of femoral fixation, rupture of the posterior cortical bone and screw divergence in relation to the tunnel direction ${ }^{(9-14)}$.

This has led to development of new fixation methods with different materials, especially using implants made of bioabsorbable material.

Recently, a system using bioabsorbable pins of 2.7 $\mathrm{mm}$ in diameter by $42 \mathrm{~mm}$ in length for bone-tendonbone fixation and $3.3 \mathrm{~mm}$ for quadruple semitendinosus-gracilis grafts was developed. Among the advantages of the system the following have been reported: greater graft-bone block contact in the tunnel (100\%); potentially less risk of rupture of the posterior cortical bone, and the possibility of graft fixation even if such situations occur; possibility of performing magnetic resonance imaging after the operation without signal interference; and, in cases of revision, the femoral tunnel will be closed and there will not be any need to remove the metal implant ${ }^{(15)}$.

This method using special guides that position two implants parallel to each other and perpendicular to the orientation of the femoral tunnel and consequently to the graft.

Because this is a recent method, there are only a few studies demonstrating the resistance and rigidity of this fixation system.

The aims of the present study were to determine the initial fixation resistance of the system using transverse bioabsorbable pins and to compare this with the traditional fixation method for bone-tendonbone grafts using $9 \mathrm{~mm}$ metal interference screws, and to evaluate the fixation resistance of this system when the rotational positioning of the bone block inside the femoral tunnel is modified.

\section{MATERIAL AND METHODS}

Forty knee (stifle joint) specimens (18 right and 22 left) from skeletally immature sheep of ages ranging from 12 to 18 months were acquired from a sheep meat trading company. After the animals had been slaughtered for human consumption, the knees were separated during the deboning process, with preservation of the femur and the proximal third of the tibia, together with the knee joint and extensor apparatus. The specimens were wrapped and preserved at $-20^{\circ} \mathrm{C}$ until the date of the surgery. At the time of the procedure, the specimens were defrosted in groups of
10 , at room temperature, before performing the surgery. From all the knees, a patellar tendon graft of $1 \mathrm{~cm}$ in width with two bone blocks was harvested. The blocks removed from the patella were $2.8 \mathrm{~mm}$ in length by $10 \mathrm{~mm}$ in diameter (Figure 1).

The tibial block was of conical shape, with a width of $2 \mathrm{~cm}$ and a depth of $2 \mathrm{~cm}$ in the proximal portion, by $3 \mathrm{~cm}$ in length. An opening was made in the most proximal portion of the patellar bone block, with the purpose of positioning a no. 5 suturing thread for graft traction. The femur of each specimen was isolated to make a tunnel of $10 \mathrm{~mm}$ in diameter, positioned in the intercondylar space and oriented at one o'clock in the left knees and at 11 o'clock in the right knees, and preserving posterior cortical bone of 1 to $2 \mathrm{~mm}$ in thickness.

For the tunnels in 20 specimens, the RigidFix ${ }^{\circledR}$ guide was adapted. This consists of two nails joined together in a $U$ shape. One of the guide nails was positioned inside the femoral tunnel and the other was external, with a device to adapt to two jackets, through which two openings were made such that they intercepted the tunnel perpendicularly, halfway along its diameter in the coronal plane (Figures 2A and 2B).

The jackets were left at the entrances to the openings in the lateral cortical bone of the femur, to serve as guides for drilling and inserting two bioabsorbable pins of diameter $2.7 \mathrm{~mm}$, through the bone blocks of the proximal end of the grafts.

To position the graft inside the femoral tunnel of the specimens, a traction thread was used at the proximal end of the bone blocks in order to enable control during insertion. Because this was a variable of interest, two forms of bone-block guidance were used for positioning the bioabsorbable pins. The first method took the orientation of the cortical part of the bone block, to

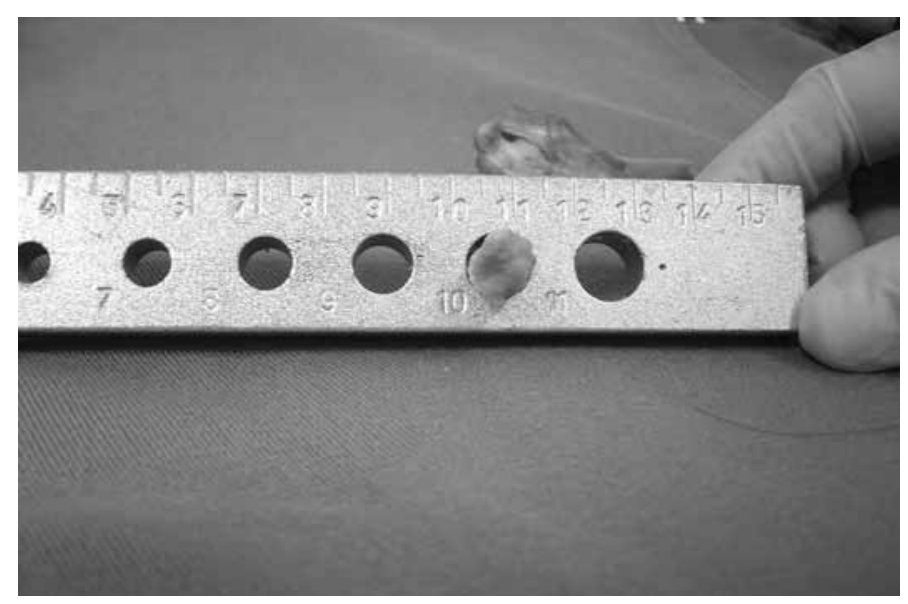

Figure 1 - Photograph of graft with bone block of $10 \mathrm{~mm}$ in diameter. 

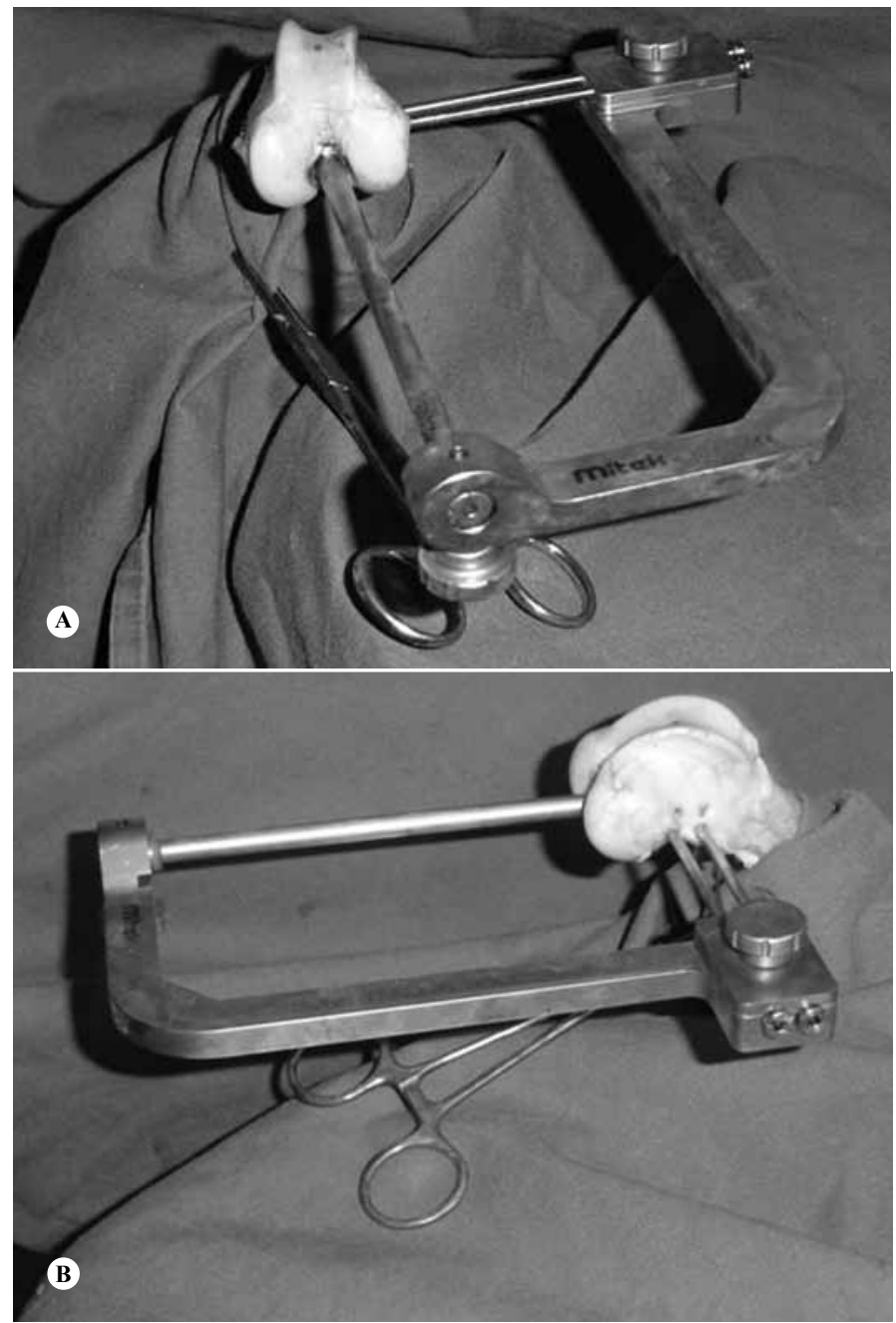

Figure 2 - Photograph demonstrating the adaptation of the Rigidfix $^{\circledR}$ guide: (A) front view; (B) side view.

allow the fixation pins to transfix the bone plate, and this was used in ten specimens. The other method allowed the pins to transfix only the spongy part of the bone block, which was used in another 10 specimens (Figure 3).

The next step was to drill the graft inside the tunnel, aided by the guide jackets and using special drills of diameter $2.7 \mathrm{~mm}$, and to insert the pins using an impacting device and hammer. The specimens were duly identified by means of adhesive tape applied to the proximal portion of the femur, and then were wrapped and refrozen at $-20^{\circ} \mathrm{C}$.

Another 20 knees were operated, taking the same care regarding defrosting, graft harvesting and construction of the femoral tunnel, as described above. The graft was placed under traction inside the tunnel in the same manner, but the graft fixation was done by using interference screws made of cannulated steel, with dimensions of $9 \mathrm{~mm}$ in diameter by $20 \mathrm{~mm}$ in length, inserted by means of Kirschner guidewires. The screws were positioned on the spongy bone, parallel to the orientation of the bone block inside the tunnel (Figure 4).

The specimens were identified regarding the fixation method using adhesive tape on the proximal portion of the femur and then were wrapped for refreezing at $-20^{\circ} \mathrm{C}$ until 24 hours before performing the tests, when they were defrosted at room temperature.

The tests were performed at the Federal Technological University of Paraná (UTFPr), on a MTS 810 universal hydraulic machine. The specimens were adapted to the machine such that traction was performed longitudinally at a velocity of $50 \mathrm{~mm} / \mathrm{min}$ (Figures $5 \mathrm{~A}$ and $5 \mathrm{~B}$ ).

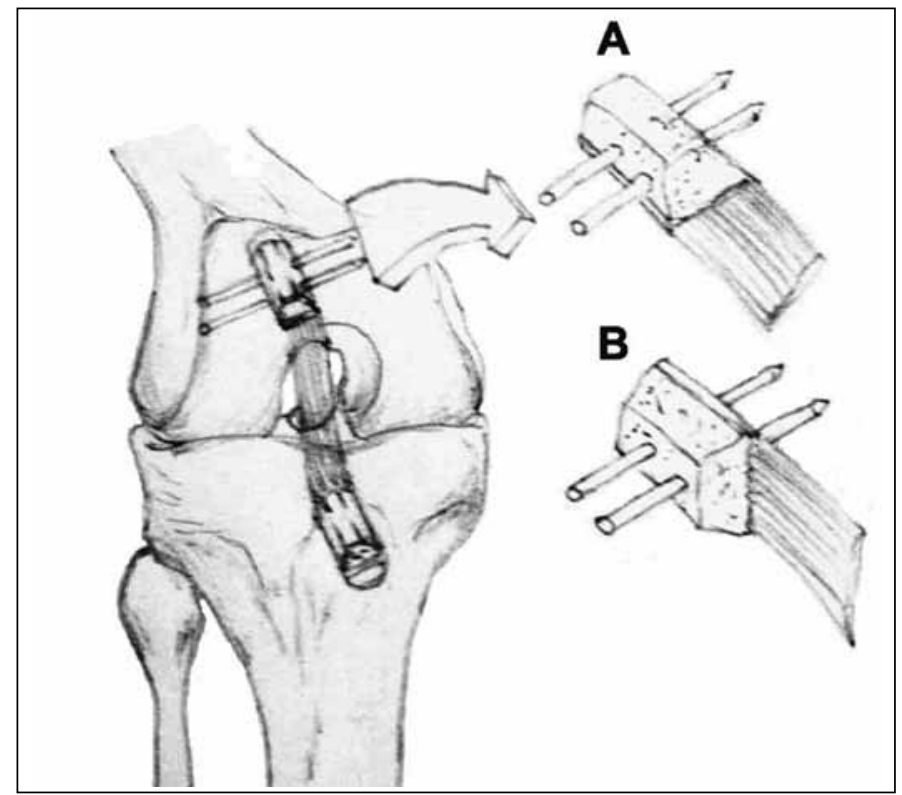

Figure 3 - Illustration demonstrating the two bone-block fixation methods using transverse pins.

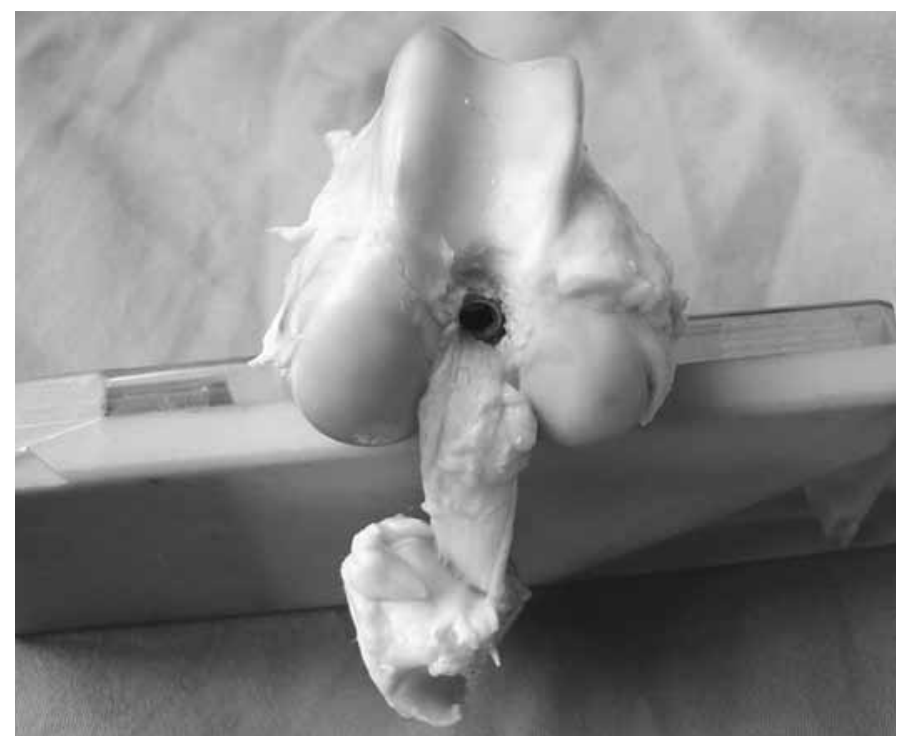

Figure 4 - Photograph of specimen fixed using interference screw. 


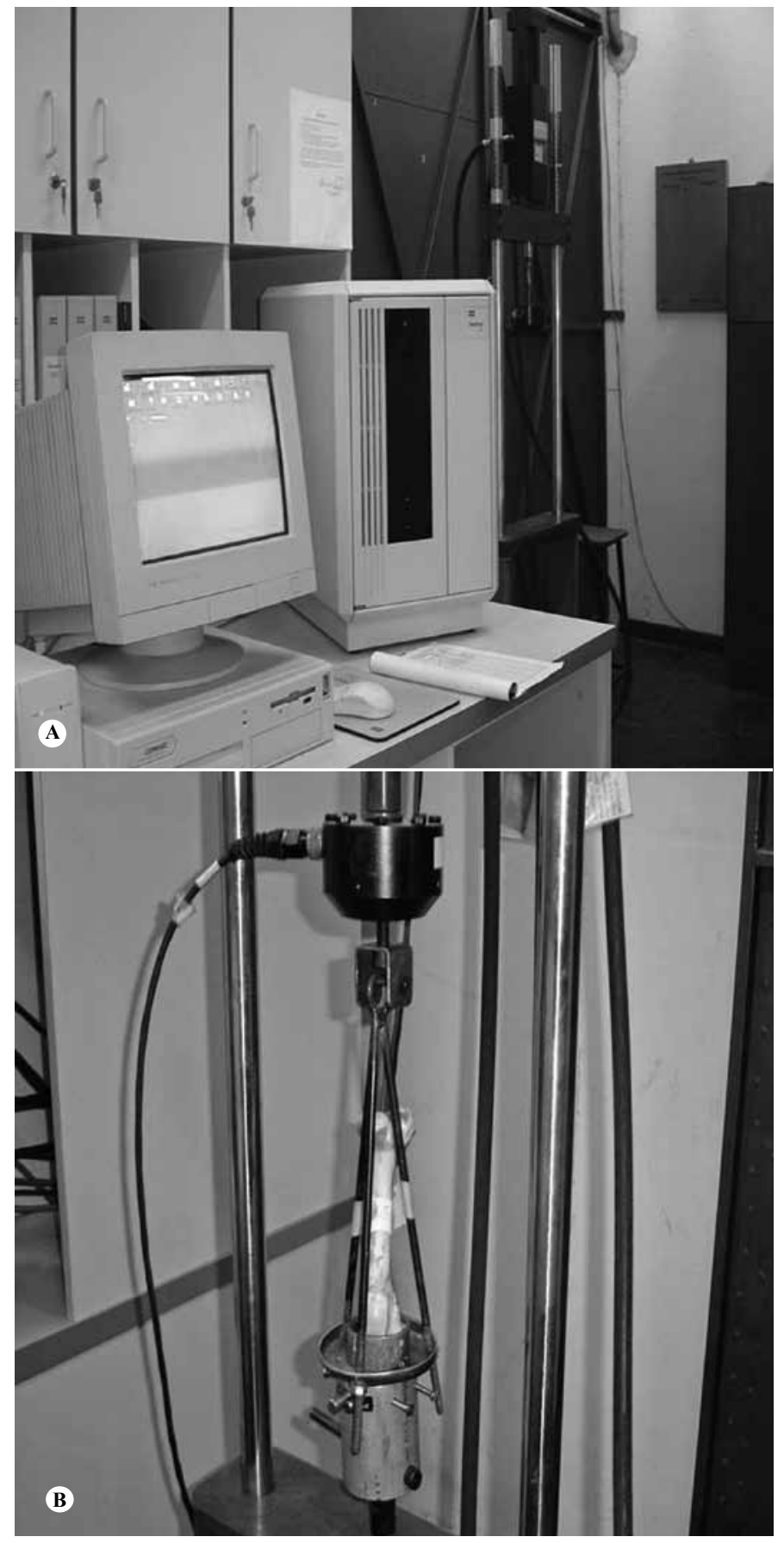

Figures $\mathbf{5 A}$ and $5 \mathbf{B}$ - Photographs showing the composition of the MTS 810 hydraulic machine.

\section{STATISTICAL ANALYSIS}

To assess the hypothesis that the variables presented normal distribution, the Shapiro-Wilks test was used. For situations in which the maximum force did not meet the condition of normal distribution, the groups were compared in pairs by means of the nonparametric Mann-Whitney test.

For the rigidity variable, which met the condition of normal distribution, the groups were compared in pairs by means of Student's t test for independent samples, taking into consideration the homogeneity of the variance. The significance level used was $p<$ 0.05 , and this was corrected using the Bonferroni multiple comparison test (values of $p<0.017$ indicated statistical significance).

\section{RESULTS}

The mean traction resistance obtained in a single cycle in the groups of transverse bioabsorbable pins did not present statistically significant differences between each other or in relation to the control group with interference screws. Table 1 and Figure 6 show the mean values of the different groups and their variations, and Table 2 shows the $\mathrm{p}$ values of the comparisons made using the nonparametric Mann-Whitney method, taking $\mathrm{p}<0.017$.

The mean rigidity results also did not show any statistically significant differences between the different fixation methods, taking $\mathrm{p}<0.017$. The mean rigidity is presented in Table 3 and the $p$ values for comparisons between the different groups are in Table 4.

The types of failure and the place of occurrence in the specimens fixed with interference screws are shown in Table 5 and Figures 7A and 7B.

Table 1 - Comparison of mean maximum loads between the methods of fixation using a metal interference screw and fixation using the RigidFix ${ }^{\circledR}$ technique to transfix the cortical and spongy bone.

\begin{tabular}{c|c|c|c|c|c|c}
\hline Group & N & Mean & Median & Minimum & Maximum & $\begin{array}{c}\text { Standard } \\
\text { deviation }\end{array}$ \\
\hline Interference & 20 & 653.7 & 677 & 112 & 963 & 180.79 \\
\hline $\begin{array}{c}\text { Pins/ } \\
\text { cortical bone }\end{array}$ & 10 & 607.5 & 598.5 & 278 & 940 & 198.7 \\
\hline $\begin{array}{c}\text { Pins/ } \\
\text { spongy bone }\end{array}$ & 10 & 710.1 & 743 & 102 & 921 & 236.09 \\
\hline
\end{tabular}

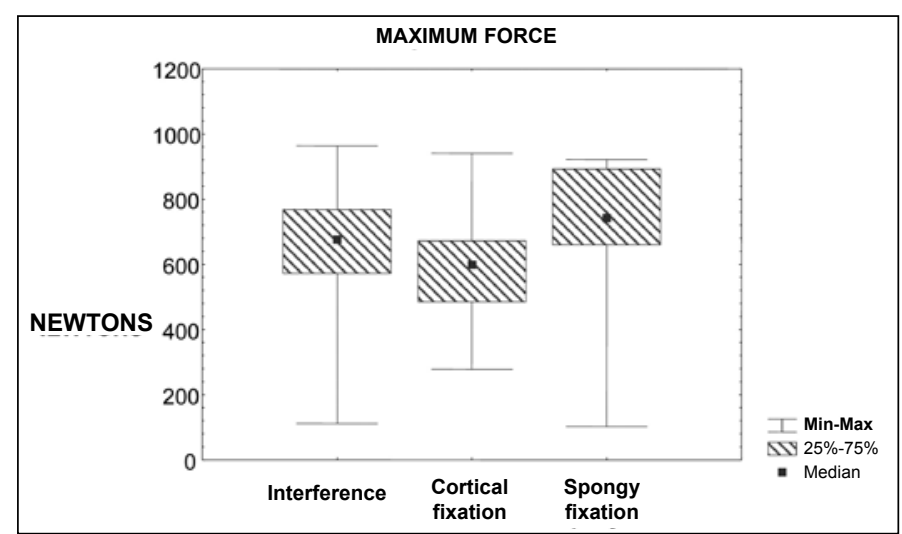

Figure 6 - Graph comparing the maximum load values between the different fixation groups: interference screw, fixation to cortical bone and fixation to spongy bone. 
Tables 6 and 7 show the places of occurrence of failures in the groups fixed with transverse pins.

Figures $8 \mathrm{~A}$ and $8 \mathrm{~B}$ show the types of failure found in the groups in which bioabsorbable transverse pins were used.

Table 2 - $\mathrm{P}$ values of comparisons made in the different groups.

\begin{tabular}{c|c}
\hline Groups under comparison & $\mathbf{p}^{*}$ value \\
\hline Interference vs. fixed in the rigid part & 0.35 \\
\hline Interference vs. fixed in the spongy part & 0.267 \\
\hline Fixed in the rigid part vs. fixed in the spongy part & 0.123 \\
\hline
\end{tabular}

Table 3 - Comparison of mean rigidity between the fixation method using a metal interference screw and the fixation method using pins transfixing to the cortical and spongy bone.

\begin{tabular}{c|c|c|c|c|c|c}
\hline Group & $\mathbf{n}$ & Mean & Median & Minimum & Maximum & $\begin{array}{c}\text { Standard } \\
\text { deviation }\end{array}$ \\
\hline $\begin{array}{c}\text { Interference } \\
\text { screw }\end{array}$ & 20 & 76.6 & 72.5 & 53 & 106 & 15.13 \\
\hline $\begin{array}{c}\text { Pin to cortical } \\
\text { bone }\end{array}$ & 10 & 65.8 & 64.5 & 38 & 103 & 22.19 \\
\hline $\begin{array}{c}\text { Pin to spongy } \\
\text { bone }\end{array}$ & 10 & 74.4 & 78 & 44 & 104 & 18.61 \\
\hline
\end{tabular}

Table 4 - Comparison of $p$ values for assessing rigidity between the fixation method using a metal interference screw and the fixation method using transverse pins to the cortical bone in one groups and spongy bone in the other group.

\begin{tabular}{c|c}
\hline Groups under comparison & $\mathbf{p}^{\star}$ value \\
\hline Interference vs fixed in rigid part & 0.127 \\
\hline Interference vs fixed in spongy part & 0.73 \\
\hline Fixed in rigid part vs fixed in spongy part & 0.36 \\
\hline
\end{tabular}

Table 5 - Types and locations of failure in the fixation method using interference screws.

\begin{tabular}{c|c|c}
\hline Types & $\begin{array}{c}\text { Number of oc- } \\
\text { currences }\end{array}$ & Percentage \\
\hline Proximal detachment & 10 & $50 \%$ \\
\hline Distal detachment & 2 & $10 \%$ \\
\hline $\begin{array}{c}\text { Loosening of screw and/or slippage } \\
\text { of bone block in femoral tunnel }\end{array}$ & 8 & $40 \%$ \\
\hline Total & 20 & $100 \%$ \\
\hline
\end{tabular}

Table 6 - Types and locations of failure in the fixation method using bioabsorbable pins fixed to the cortical bone.

\begin{tabular}{c|c|c}
\hline Types & Number of occurrences & Percentage \\
\hline Proximal detachment & 0 & \\
\hline Distal detachment & 2 & $20 \%$ \\
\hline $\begin{array}{c}\text { Fracture of bone block } \\
\text { Failure of implant in femoral } \\
\text { tunnel }\end{array}$ & 6 & $60 \%$ \\
\hline total & 2 & $20 \%$ \\
\hline
\end{tabular}
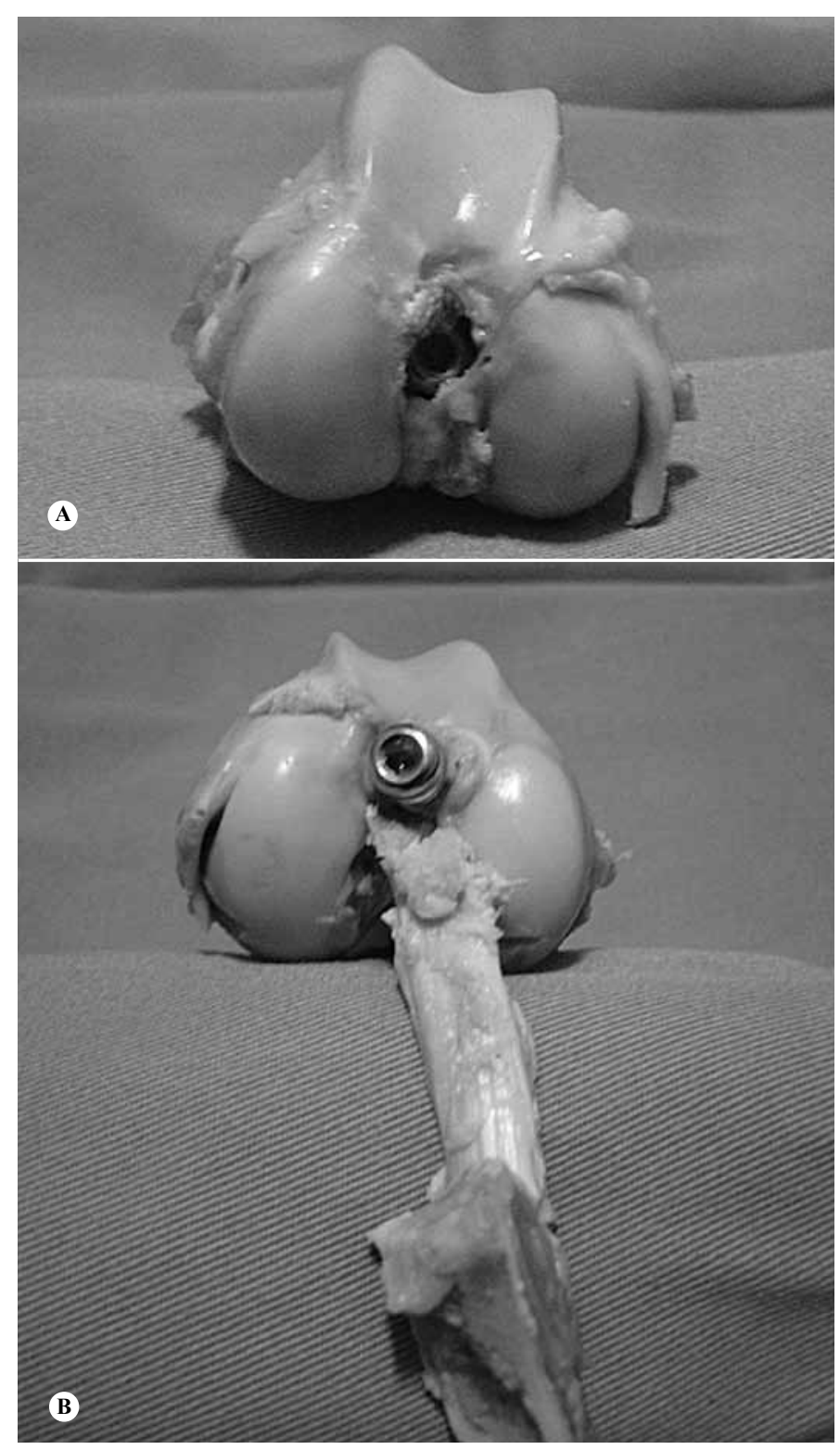

Figures 7A and 7B - Photographs of specimens showing locations and most frequent types of failure found in the fixation method with interference screws.

Tabela 7 - Tipos e local de falha no método de fixação com RigidFix $^{\circledR}$, fixação na esponjosa.

\begin{tabular}{c|c|c}
\hline Tipos & $\begin{array}{c}\text { Número de ocor- } \\
\text { rências }\end{array}$ & Porcentagem \\
\hline $\begin{array}{c}\text { Destacamento na } \\
\text { tot Proximal }\end{array}$ & 1 & $10 \%$ \\
\hline Destacamento na tot Distal & 2 & $20 \%$ \\
\hline Fratura do bloco ósseo I & 5 & $50 \%$ \\
\hline $\begin{array}{c}\text { Falha do implante no } \\
\text { túnel femoral }\end{array}$ & 1 & $10 \%$ \\
\hline $\begin{array}{c}\text { Rompimento do tendão } \\
\text { no 1/3 médio }\end{array}$ & 1 & $10 \%$ \\
\hline Total & 10 & $100 \%$ \\
\hline
\end{tabular}




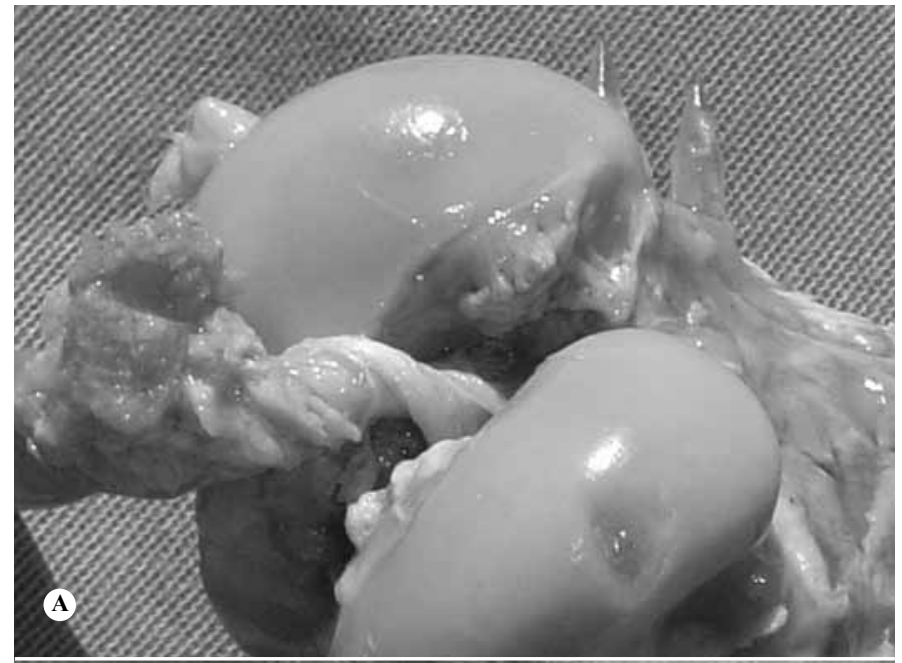

B

Figures $\mathbf{8 A}$ and $\mathbf{8 B}-$ Photograph showing types of failure in the method with bioabsorbable pins.

\section{DISCUSSION}

In the literature, there are few studies evaluating this method experimentally ${ }^{(16-18)}$ and none that present or discard the possibility of fixation of a bone-tendon-bone graft by means of the spongy portion of the bone block. Based on this point, we decided to evaluate the method that uses $2.7 \mathrm{~mm}$ bioabsorbable pins, with two different types of fixation relating to graft rotation inside the tunnel, and to compare these two types with the method that uses $9 \mathrm{~mm}$ metal interference screws.

The initial hypothesis in subdividing the group in which the bioabsorbable pins were used was that fixation of implants by means of the cortical face of the bone block of the graft inside the femoral tunnel would be more resistant to traction forces than would passage of the pins solely into the spongy bone. In doing the tests, no statistically significant difference was found, taking $\mathrm{p}<0.017$ between the two subgroups.

Passage of the $2.7 \mathrm{~mm}$ pin through the cortical bone caused fragility in this more resistant portion of the graft, and therefore the resistance depended almost exclusively on the resistance of the two columns parallel to the more distal hole of the graft. This is the commonest site for fractures in this type of fixation (60\% in this experiment).

In the group fixed with pins in the spongy bone, the tendon structure continued to be in line with the bone plate and therefore the traction forces were transmitted through the cortical bone. The more resistant bone plate remained intact, without holes for the pins to pass through, thus allowing transmission of the traction forces to the proximal pin. The resistance of the fixation depended on the density of the spongy bone and its adherence to the cortical bone, and the resistance to traction may have come from the sum of the two pins, thereby partially compensating for the lower resistance of this portion of the graft.

In the present study, blocks of $10 \mathrm{~mm}$ in diameter were used, taking into consideration the work performed by Zantop et $\mathrm{al}^{(17)}$, who used the same experimental model and observed that the diameter of the bone block was an important factor in the resistance of the fixation when using transfixing pins. These authors recommended against using blocks smaller than $9 \mathrm{~mm}$ in diameter.

The absence of soft tissues in the experimental model made it easier to check the positioning of the transverse holes created for passing the bioabsorbable pins into the femoral tunnel. This did not add any technical difference in carrying out the experimental surgery, given that in humans, this observation method is frequently used with the aid of a camera placed by means of the tibial tunnel ${ }^{(19)}$.

Placement of the specimen at an angle in order to align the direction of traction produced by the machine with the orientation of the tunnel leads to the belief that, both in the case of the screw and in the case of the bioabsorbable implant, the resistance could be greater given that the axis of the forces acting on the knee under normal conditions of movement act tangentially to the joint line ${ }^{(8)}$.

Sheep were used as the experimental model because of the similarity of the anatomical properties and because they have been accepted as an experimental model in evaluating reconstructions of the anterior cruciate ligament ${ }^{(20-27)}$.

It is not expected that the present study will lead 
to any modification of the technique for inserting bioabsorbable implants for fixation of bone-tendon-bone grafts. There will certainly be a need to conduct further tests on cyclical traction, in order to demonstrate whether this technical variant would be sufficiently secure in cases of necessity.

\section{CONCLUSION}

Comparison of the method using $2.7 \mathrm{~mm}$ bioabsorbable pins for fixation of a bone-tendon-bone graft transversely inside the femoral tunnel with the fixation method using an interference screw did not shown any statistically significant difference with regard to maximum load and rigidity for the initial fixation in a single traction cycle.

With this experimental model, similar resistance was obtained for bone block fixations in the femoral tunnel using bioabsorbable pins transfixed solely in spongy bone and using pins transfixing the cortical bone plate.

\section{Acknowledgement}

The authors express their gratitude to Dr Carlos Henrique Ramos, who drew the illustration for Figure 3, demonstrating the two types of bone block fixation using transverse pins.

\section{REFERENCES}

1. Shelbourne KD, Nitz P. Accelerated rehabilitation after anterior cruciate ligament reconstruction. Am J Sports Med. 1990;18(3):292-9.

2. Brand J Jr, Weiler A, Caborn DN, Brown CH Jr, Johnson DL. Graft fixation in cruciate ligament reconstruction. Am J Sports Med. 2000;28(5):761-74.

3. Snyder-Mackler L, Delitto A, Bailey SL, Stralka SW. Strength of the quadríceps femoris muscle and functional recovery after reconstruction of the anterior cruciate ligament. A prospective, randomized clinical trial of electrical stimulation. $\mathrm{J}$ Bone Joint Surg Am. 1995;77(8):1166-73.

4. Arnoczky SP, Tarvin GB, Marshall JL. Anterior cruciate ligament replacement using patellar tendon. An evaluation of graft revascularization in the dog. J Bone Joint Surg Am. 1982;64(2):217-24.

5. Noyes FR, Butler DL, Grood ES, Zernicke RF, Hefzy MS. Biomechanical analysis of human ligament grafts used in knee-ligament repairs and reconstructions. J Bone Joint Surg Am. 1984;66(3):344-52.

6. Kurosaka M, Yoshiya S, Andrish JT. A biomechanical comparison of different surgical techniques of graft fixation in anterior cruciate ligament reconstruction. Am J Sports Med. 1987;15(3):225-9.

7. Abate JA, Fadale PD, Hulstyn MJ, Walsh WR. Initial fixation strength of polylactic acid interference screws in anterior cruciate ligament reconstruction. Arthroscopy. 1998;14(3):278-84.

8. Fu FH, Bennett $\mathrm{CH}$, Lattermann $\mathrm{C}$, Ma $\mathrm{CB}$. Current trends in anterior cruciate ligament reconstruction. Part 1: Biology and biomechanics of reconstruction. Am J Sports Med. $1999 ; 27(6): 821-30$.

9. Brown $\mathrm{CH} \mathrm{Jr}$, Carson EW. Revision anterior cruciate ligament surgery. Clin Sports Med. 1999;18(1):109-71.

10. Kousa $P$, Järvinen TL, Kannus $P$, Ahvenjärvi $P$, Kaikkonen $A$, Järvinen $M$. A bioabsorbable plug in bone-tendon-bone reconstruction of the anterior cruciate ligament: Introduction of a novel fixation technique. Arthroscopy. 2001;17(2):144-50.

11. Matthews LS, Soffer SR. Pitfalls in the use of interference screws for anterior cruciate ligament reconstruction: brief report. Arthroscopy. 1989;5(3):225-6

12. Allum R. Complications of arthroscopic reconstruction of the anterior cruciate ligament. J Bone Joint Surg Br. 2003 Jan;85(1):12-6.

13. Azar FM, Arthur ST. Complications of anterior cruciate ligament reconstruction. Techn Knee Surg. 2004;3:238-50.

14. Pierz K, Baltz M, Fulkerson J. The effect of Kurosaka screw divergence on the holding strength of bone-tendon-bone grafts. Am J Sports Med. 1995;23(3):332-5.

15. Johnson \& Johnson Gateway. RIGIDFIX®: ACL Cross Pin System. Disponível em: www.jnjgateway.com

16. Weimann A, Zantop T, Rümmler M, Hassenpflug J, Petersen W. Primary stability

of bone-patellar tendon-bone graft fixation with biodegradable pins. Arthroscopy. 2003;19(10):1097-102.

17. Zantop T, Ruemmler M, Welbers B, Langer M, Weimann A, Petersen W. Cyclic loading comparison between biodegradable interference screw fixation and biodegradable double cross-pin fixation of human bone-patellar tendon-bone grafts. Arthroscopy. 2005;21(8):934-41.

18. Milano G, Mulas PD, Ziranu F, Deriu L, Fabbriciani C. Comparison of femoral fixation methods for anterior cruciate ligament reconstruction with patellar tendon graft: a mechanical analysis in porcine knees. Knee Surg Sports Traumatol Arthrosc. 2007;15(6):733-8.

19. Chandratreya AP, Aldridge MJ. Top tips for RIGIDfix femoral fixation. Arthroscopy. 2004;20(6):e59-61.

20. Zantop T, Weimann A, Wolle K, Musahl V, Langer M, Petersen W. Initial and 6 weeks postoperative structural properties of soft tissue anterior cruciate ligament reconstructions with cross-pin or interference screw fixation: an in vivo study in sheep. Arthroscopy. 2007;23(1):14-20.

21. Jackson DW, Grood ES, Arnoczky SP, Butler DL, Simon TM. Cruciate reconstruction using freeze dried anterior cruciate ligament allograft and a ligament augmentation device (LAD). An experimental study in a goat model. Am J Sports Med. 1987;15(6):528-38.

22. Schindhelm K, Rogers GJ, Milthorpe BK, Hall PJ, Howlett CR, Sekel R, et al. Autograft and Leeds-Keio reconstructions of the ovine anterior cruciate ligament. Clin Orthop Relat Res. 1991;(267):278-93.

23. Drez DJ Jr, DeLee J, Holden JP, Arnoczky S, Noyes FR, Roberts TS. Anterior cruciate ligament reconstruction using bone-patellar tendon-bone allografts. A biological and biomechanical evaluation in goats. Am J Sports Med. 1991;19(3):256-63.

24. Jackson DW, Grood ES, Goldstein JD, Rosen MA, Kurzweil PR, Cummings $\mathrm{JF}$, et al. comparison of patellar tendon autograft and allograft used for anterior cruciate ligament reconstruction in the goat model. Am J Sports Med. 1993;21(2):176-85.

25. Walton M. Absorbable and metal interference screws: comparison of graft security during healing. Arthroscopy. 1999;15(8):818-26.

26. Boszotta $\mathrm{H}$, Anderl W. A primary stability with tibial press-fit fixation of patellar ligament graft: a experimental study in ovine knees. Arthroscopy. 2001;17(9):963-970.

27. Silva JLV, Tavares Filho GS, Namba MM, Pereira Filho FA, Barbosa MA, Albano $M$, et al. Estudo biomecânico, "in vitro", em ovinos, da fixação femoral do tendão patellar na reconstrução do LCA: comparação entre parafusos metálicos de interferência e a fixação sob pressão com bloco ósseo cônico. Rev Bras Ortop. 2003;38(2):400-9 